\title{
ENTREPRENEURSHIP OVER THE BUSINESS CYCLE
}

\author{
$\mathrm{Li} \mathrm{Yu}^{\mathrm{a}}{ }^{\mathrm{a}}$, Peter F. Orazem ${ }^{\mathrm{b}}$ and Robert W. Jolly ${ }^{\mathrm{b}}$ \\ a Central University of Finance and Economics \\ b Iowa State University
}

\begin{abstract}
The fraction self-employed rises in recessions because wage work is more sensitive than self-employment to the business cycle, not because of necessity entrepreneurship. Graduating during a recession reduces the probability of starting a business for the next 11 years.
\end{abstract}

Key words: Entrepreneurship; Boom; Bust; Delay; Graduates

JEL code: J2

${ }^{1}$ Corresponding author is Li Yu, 39 S College Rd, China Center for Human Capital and Labor Market Research, Central University of Finance and Economics, Beijing, 100081, China. Phone: +86 106228 8917. Fax: +86 106228 8298. E-mail: yuli.isu@gmail.com. 


\section{Introduction}

There are two competing views of the role of business cycles on self-employment ${ }^{2}$. Some contend that during recessions, unemployed laid-off workers or the unemployed are pushed into self-employment because of weak labor market opportunities (Evans and Leighton, 1989; Constant and Zimmermann, 2004 to name a few). More recently, Fairlie (2013) finds a positive and significant relationship between local unemployment rates and the probability of new business start-ups, using data from the Current Population Survey 1996-2009. ${ }^{3}$

Other researchers have found conflicting evidence regarding the relationship between unemployment rates and business start-ups. Blanchflower (2000) reports a negative relationship between the self-employment rate and the unemployment rate in most OECD countries. Shane (2011) finds that the Great Recession in the U.S. was a time of considerable decline in entrepreneurial activity. To round out all possible conclusions, Moore and Mueller (2002) found that self-employment decisions are uncorrelated with the unemployment rate.

There are several reasons to be suspicious of the recession-push story. Constraints on borrowing would retard entrepreneurial activity, which is more prevalent in downturns (Cagetti and De Nardi, 2006; Holtz-Eakin, et al, 1994; Blanchflower and Oswald, 1998; Fairlie, 1999). Additionally, people tend to be more risk averse in economic downturns, and more agents become entrepreneurs during expansions because agents are more willing to bear risk (Rampini, 2004).

\section{The positive bias in the correlation between entrepreneurship and unemployment rates}

\footnotetext{
${ }^{2}$ See the literature review by Meager (1992) and Parker (2009), presenting mixed evidence regarding the importance of necessity entrepreneurship because of lacking better opportunities in wage employment in worse economic conditions.

${ }^{3}$ The individual is viewed as starting a business if in the next month business ownership is the job requiring the most hours relative to wage work. The entrepreneurship rate is defined as the percentage of the population of nonbusiness owners during one month who own a business as their main job in the subsequent month.
} 
To begin, we demonstrate that entrepreneurship is less sensitive to the business cycle than is wage and salary employment. That result creates an artificial positive relationship between changes in the unemployment rate and changes in the entrepreneurship rate. Let the entrepreneurship share be defined as $S_{t}=\frac{P R_{t}}{P R_{t}+E_{t}}$ where $P R_{t}$ is the number of proprietors and $E_{t}$ is the number of wage and salary employees as reported by the Bureau of Economic Analysis (BEA). We measure the business cycle by the unemployment rate for men aged 25 and over as reported by the BEA, the rate most commonly used as a measure of the state of the labor market because it is least influenced by discouraged unemployment during economic downturns. As shown in Fig. 1(a), the proprietorship share rises with increases in the unemployment rate. After controlling for time trend, a percentage increase in the unemployment rate increases the proportion of proprietors in the population by 0.16 , approximately 0.05 larger than the effect found by Fairlie (2013). One could easily conclude from such data that economic downturns push people into entrepreneurship.

However, the entrepreneurship share is a ratio which can increase because of an increase in the numerator (number of proprietors) or because of a decrease in the denominator (the sum of proprietors plus wage and salary workers) or both. It is straightforward to show that the ratio increases if wage and salary employment fall faster than proprietorships in economic downturns. As a result, rising unemployment rates create the appearance of rising entrepreneurship rates even if the number of proprietors is declining. That is what happens as shown in Figures 1(b-c). Wage and salary employment is very sensitive to the business cycle: one percentage increase in the unemployment rate is associated with a significant $0.6 \%$ decrease in wage and salary employment. Furthermore, $87 \%$ of variation in the change of log paid employment can be explained by changes in the unemployment rate and a time trend. 
The change in the log of self-employment is also negatively correlated with increasing unemployment rates but only weakly. Fig. 1(c) shows that one percentage increase in the unemployment rate lowers proprietorships by $0.06 \%$, one-tenth the size of the effect on wage employment. Even though the number of proprietorships declines in recessions, the ratio of proprietors to total employment rises.

This data represents spurious support of the push theory. The bias is most apparent when the entrepreneurship rate is measured relative to total employment. It is smaller when the rate is measured relative to the total population as in the Fairlie (2013) study. However, even that analysis is biased toward necessity entrepreneurship. Some individuals, who share time between work for pay and a side business will lose wage employment to their business, will be listed as starting a business in the following month. These false start-ups will be greatest in number when the unemployment rate is rising.

\section{Recessions and Life-time Entrepreneurship}

The investigation of whether or not entrepreneurship varies with the business cycle has largely ignored the life-cycle perspective of occupational choice. That perspective suggests that individuals choose occupations with an eye toward expected future returns rather than transitory incomes (Orazem and Mattila, 1991). Empirical models of self-employment have generally focused on permanent or quasi-fixed factors such as demographic attributes, education, or industry- or location-specific human capital to explain variation in entrepreneurial entry (Fairlie and Meyer, 2000; Hout and Rosen, 2000; Lazear, 2005; Fairlie and Robb, 2007). That focus is natural in that entrepreneurial returns are only realized after a long delay (Hamilton, 2000).

Nevertheless, we have solid evidence that graduating in a recession can have significant and persistent effects on earnings. Kahn (2010) found that male college graduates who enter 
employment in periods of high unemployment rates face significant wage losses relative to college graduates who start employment in economic expansions. These wage losses do not start to diminish until 10 years past graduation and remained statistically significant 15 years after graduation. Oreopoulos et al (2012) found that Canadian college graduates entering in recessed labor markets faced persistent earnings losses for 10 years. In the life-cycle context, unemployment rates at graduation may not alter the probability that an individual ever starts a business but it may accelerate or delay the age at which individuals enter self-employment.

We test the impact of the business cycle on the timing of entrepreneurship using a survey of Iowa State University (ISU) Bachelor’s degree recipients graduating between 1982 and 2007. The sample period includes the severe 1982 recession as well as the 1992-2001 expansion of the U.S. economy. Each respondent reported whether they had ever started a for-profit-business, and if yes, the date of the start-up. The data set includes additional information on demographics, family background, high school academic performance, ACT or SAT score, extra-curricular activities, college major, mix of classes and the student's academic performance at college, allowing a uniquely strong set of controls for individual ability, family background, and type of training as well as a unique opportunity to explore the possible persistence of recessions on entrepreneurial entry.

Using a probit specification, we examine successively whether each individual started a business within $t$ years of graduation,

$$
E_{i}^{g t *}=\gamma^{t} U^{g}+\beta^{t} X_{i}^{g}+\varepsilon_{i}^{t}, t=2,3, \ldots, 15 .
$$

The corresponding dependent variable of its latent variable $E_{i}^{g t *}$ in the probit model is dichotomous with 1 indicating the respondent $i$ who graduated at year $g$, started a business within $t$ years of graduation. The variable $U^{g}$ measures unemployment rate at graduation. The 
regressions included the full set of regressors $X_{i}^{g}$ controlling for family background, ability, major, academic performance and demographics before entering the labor market. $\varepsilon_{i}^{t}$ is an idiosyncratic disturbance term within $t$ years after individual $i$ 's graduation. $\gamma^{t}, t=2,3, \ldots, 15$ are a series of the estimated coefficients of economic conditions upon graduation on entrepreneurship in the following $t$ years. We only report the marginal effect of the Iowa unemployment rate at the time of graduation and their $95 \%$ confidence intervals. ${ }^{4}$ We use the Iowa unemployment rate as our business cycle indicator because 33\% of ISU alumni live in Iowa and 32\% of the businesses started by alumni are located in the state. Because college graduation timing could be potentially be affected by economic conditions, which makes unemployment rate in Iowa potentially endogenous in our settings since students may take into account business cycle conditions when choosing the time and place of college graduation, we instrument for the unemployment rate using student's birth year, following the approach adopted in Kahn (2010) . ${ }^{5}$

The results are illustrated in Fig. 2. From $t=2,3, \ldots, 11$, a one percent increase in the unemployment rate at graduation lowers the marginal probability of starting a business by around 0.05 . Beyond 11 years after graduation, the negative effect dissipates and ultimately reverses. ${ }^{6}$ The implication is that graduating in a bust market delays entrepreneurial entry but does not permanently reduce the probability of starting a business at some point in the life cycle.

There are other differences between the entrepreneurial ventures of boom and bust cohorts that suggest mechanisms that may affect the timing of business start-ups. Table 1 contrasts two groups: a bust cohort of entrepreneurs who graduated in 1982 and 1983, a period that included

\footnotetext{
${ }^{4}$ Sample weights are used to correct for differences in probability of response between survey years and between alumni within survey years. Regressions are available on request.

${ }^{5}$ As $t$ increases, the sample size diminishes which will affect the precision of the estimates, but the marginal effect on unemployment rate at the time of graduation should not be biased. The latest cohort graduated in 2007. Our sample for each regression will include all graduates between 1982 and $2007-t$. For example, $t=4$ allows us to include graduates through 2003; $t=8$ allows us to include graduates through 1999; and so on.

${ }^{6}$ Although not the main focus of their study, Black and Strahan (2002) found that local personal income growth positively affects new incorporations for 6 years.
} 
the highest unemployment rate since World War II; and a boom cohort of entrepreneurs that graduated in 1992 and 1993: the start of the longest lived economic expansion in the history of the United States. Boom cycle entrepreneurs relied more heavily on self-financing for their startups (88\% vs. 73\%). Kahn (2010) and Oreopoulos et al (2012) showed that bust cohort college graduates face lower wages compared to boom cohort graduates that persist for more than a decade, consistent with our finding that bust cohort entrepreneurs have less ability to self-finance their ventures.

The bust cohort entrepreneurs were significantly $14 \%$ less likely to have retained ownership over the 15 year period following graduation than were boom cohort entrepreneurs, ceteris paribus. The difference in firm retention rates does not appear to be attributable to differences in entrepreneurial ability because the gap disappears when we standardize the year of startup. There are also differences in the reasons leading to firm exits, although our small samples of exiting entrepreneurs compromises the precision of our results. Bust cohort entrepreneurs were more likely to exit because the venture failed (29\% versus $11 \%)$ although the difference fails standard significance tests. Boom cohort entrepreneurs were more likely to exit the business voluntarily when it was still a going concern. It may well be easier for the boom cohort to walk away from a venture because the relatively strong labor market offered better employment options and the stronger market for capital offered better exit terms than did the relatively slack labor and capital markets faced by the bust cohort entrepreneurs.

\section{Conclusion}

This study shows that labor market flows create a positive correlation between unemployment rates and the share of proprietors in the labor market that can be incorrectly interpreted as evidence of necessity entrepreneurship. Data on college graduates shows that entering the labor 
market during adverse economic conditions lowers the probability of starting a business for eleven years after graduation, but entrepreneurial dreams are not dashed but only deferred. Individuals were less likely to self-finance their ventures, consistent with evidence that graduating in a recession persistently lowers labor market earnings over a long time frame. 
Fig. 1: Relationship between unemployment rate changes and changes in the share of proprietors in the labor market, the change in paid employment and the change in proprietors, 1970-2011
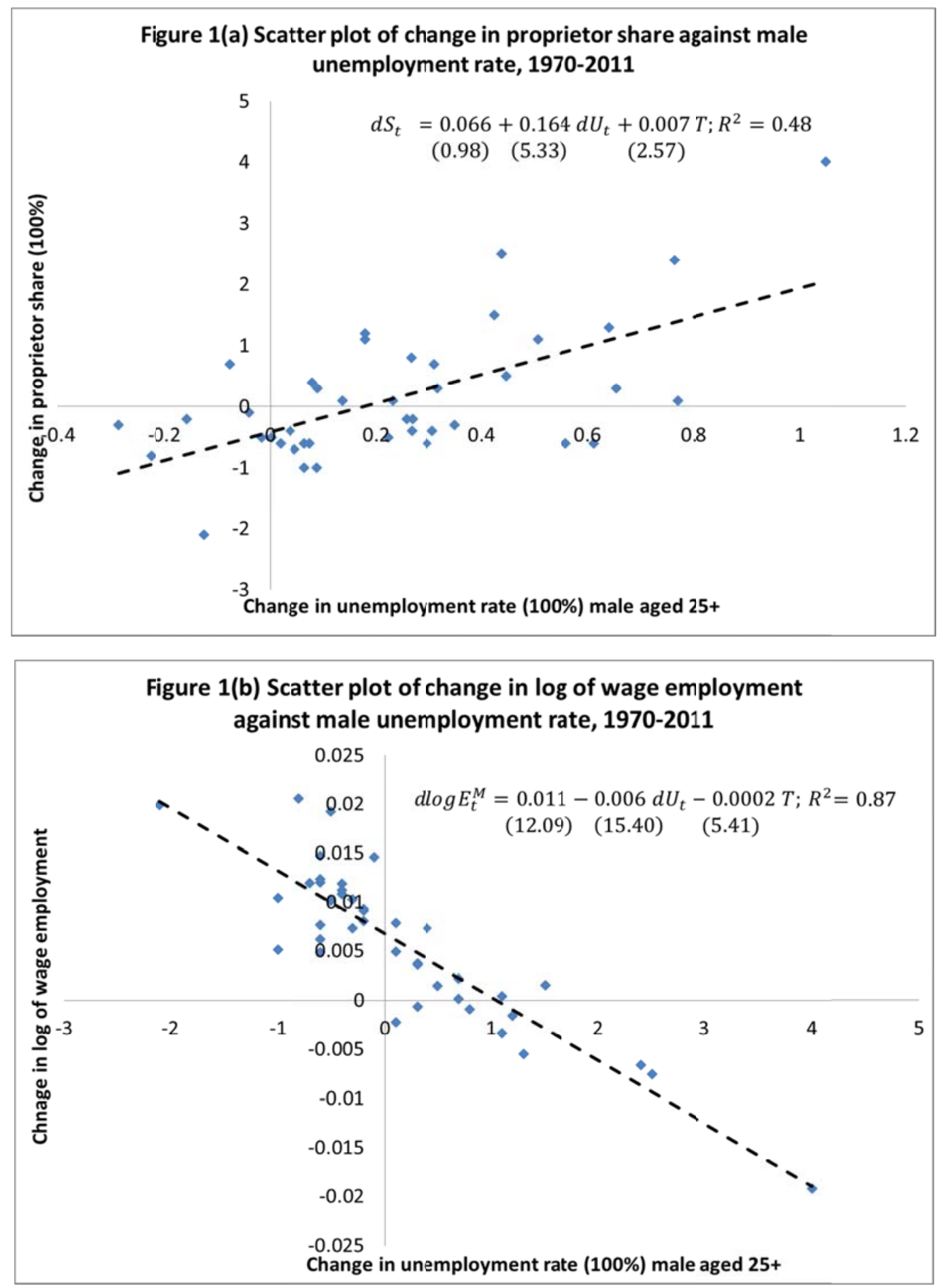


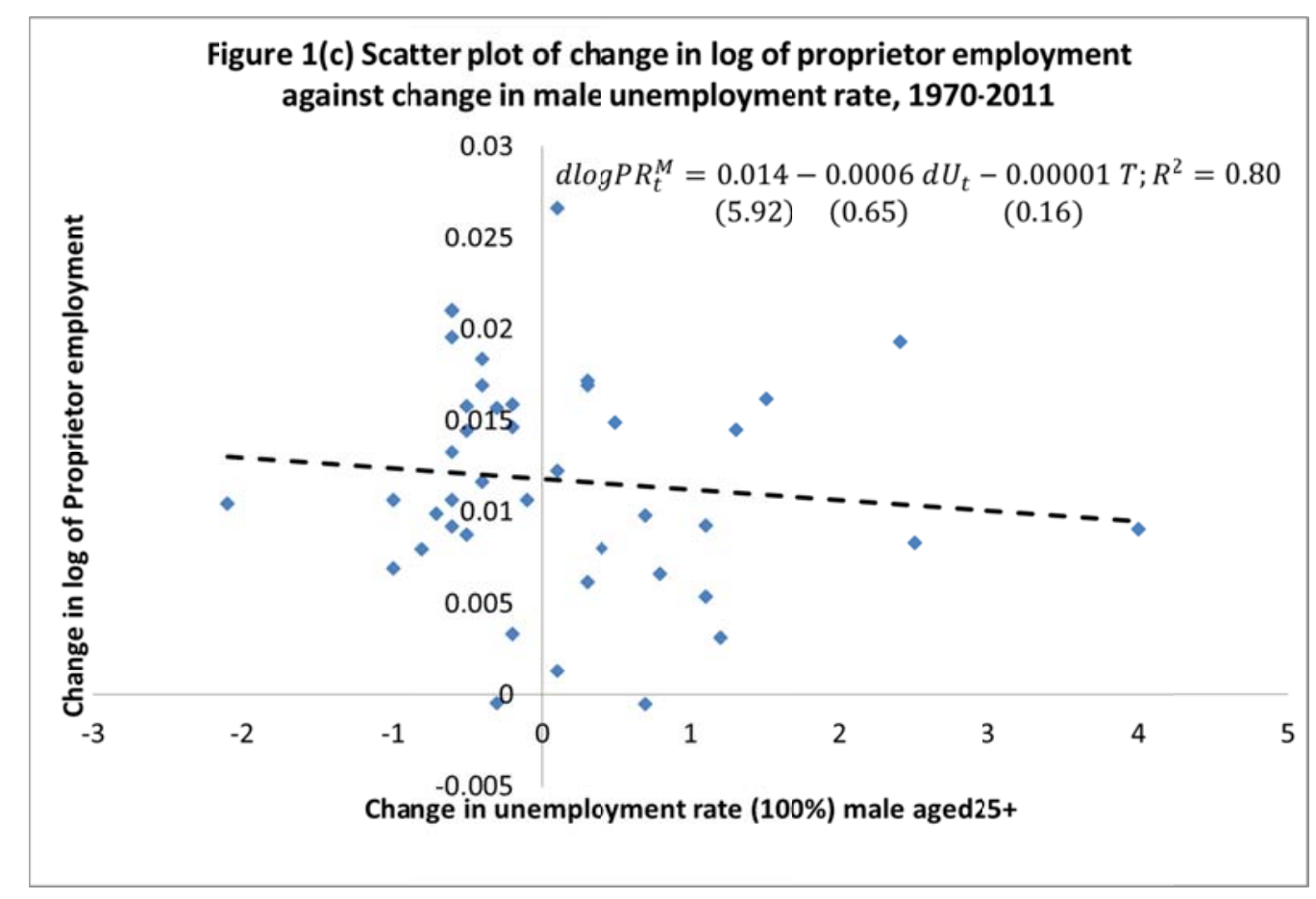

Data source: Regional Economic Information System, Bureau of Economic Analysis, U.S. Department of Commerce http://www.bea.gov/regional/spi/default.cfm?selTable=SA25N\&selSeries=NAICS. 
Fig. 2 Estimated marginal effect of the unemployment rate at time of graduation on probability of starting a business by years since graduation, 1982-2007

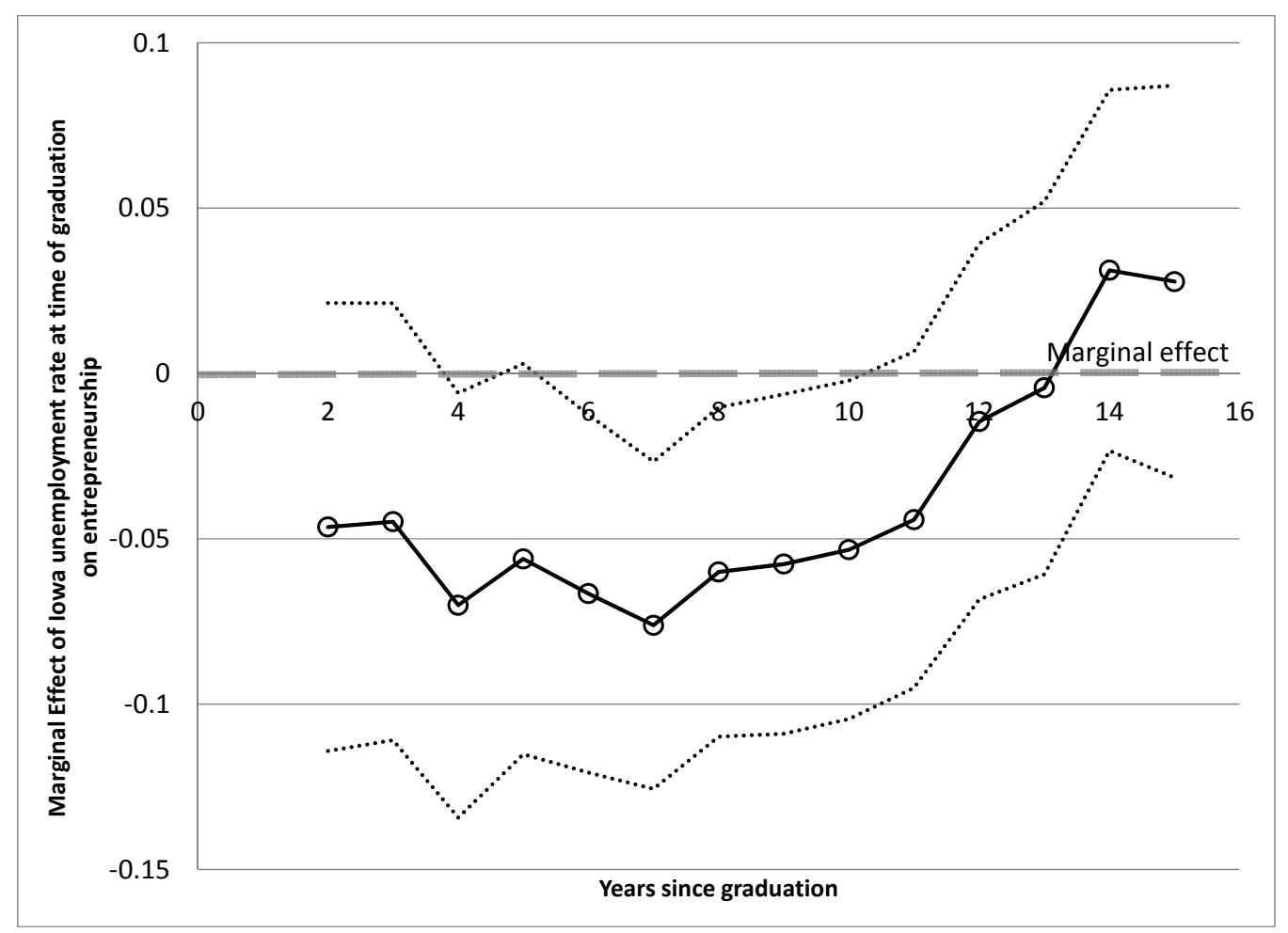

Estimates based on successive instrumental probit models explaining the probability that Iowa State University graduates started a business within T years of graduation. Model also includes measures of college major, demographics, parental education and business experience, and academic performance in high school and college. Dashed lines represent the 95\% confidence interval. We instrument Iowa unemployment rate for birth year of students. 
Table 1 Comparisons between entrepreneurs in boom (1992-93) and bust (1982-3) cohorts

\begin{tabular}{|c|c|c|c|c|c|c|}
\hline \multirow[b]{2}{*}{ Variables } & \multicolumn{2}{|c|}{ Cohort 1982 \& 1983} & \multicolumn{2}{|c|}{ Cohort 1992 \& 1993} & \multicolumn{2}{|c|}{ Difference } \\
\hline & Mean $_{1}$ & Std $\operatorname{Err}_{1}$ & Mean $_{2}$ & Std $\operatorname{Err}_{2}$ & $\mathrm{Mean}_{2-}$ Mean $_{1}$ & t-value \\
\hline \multicolumn{7}{|l|}{ Financina business } \\
\hline Self financed & 0.731 & 0.064 & 0.880 & 0.037 & 0.149 & $2.02^{* *}$ \\
\hline Loan or gift from familv members & 0.113 & 0.037 & 0.068 & 0.020 & -0.045 & -1.07 \\
\hline Loan from a local bank & 0.258 & 0.056 & 0.190 & 0.047 & -0.068 & -0.93 \\
\hline Loan from a non-local bank & 0.019 & 0.010 & 0.018 & 0.009 & -0.001 & -0.10 \\
\hline Financed from outside investors & 0.025 & 0.012 & 0.079 & 0.033 & 0.054 & 1.55 \\
\hline Government grants to finance & 0.004 & 0.004 & 0.033 & 0.017 & 0.029 & $1.61^{*}$ \\
\hline \multicolumn{7}{|l|}{ Retained Ownership } \\
\hline RetentionRate ${ }^{a}$ & 0.603 & 0.069 & 0.742 & 0.058 & $0.442^{\mathrm{C}}$ & $2.08 * *$ \\
\hline Retention Rate ${ }^{\mathrm{b}}$ & 0.650 & 0.059 & 0.742 & 0.058 & $0.088^{\mathrm{C}}$ & 0.46 \\
\hline \multicolumn{7}{|l|}{ Exit reasons } \\
\hline I sold it or passed it down & 0.369 & 0.107 & 0.131 & 0.056 & -0.238 & $-1.98 * *$ \\
\hline It was not successful & 0.288 & 0.088 & 0.114 & 0.068 & -0.174 & -1.56 \\
\hline I no longer wished to own the business & 0.343 & 0.092 & 0.755 & 0.091 & 0.413 & $3.18 * * *$ \\
\hline
\end{tabular}

Note: $*$, ** and *** indicate significance at 10\%, 5\% and 1\% respectively. "Std Err" represents standard error of the mean estimates.

a: The proportion of entrepreneurs who still have ownership of a business started during the first fifteen years after graduation.

b: The proportion of entrepreneurs who still have ownership of a business started between 1992 and 2007

c: Coefficient on the boom cohort dummy from a logit model predicting whether respondent still owns a firm, controlling for the regressors included in

Figure 2. Associated z-statistic is reported in the next column. 


\section{Appendix}

Table A1. Summary statistics of alumni characteristics

\begin{tabular}{|c|c|c|c|c|c|c|c|c|}
\hline \multirow[b]{2}{*}{ Variables } & \multicolumn{2}{|c|}{1982 Cohort } & \multicolumn{2}{|c|}{1992 Cohort } & \multicolumn{2}{|c|}{ Cohorts 1982 \& 1992} & \multicolumn{2}{|c|}{$\begin{array}{c}\text { Cohort 1982, 1983, } \\
1992,1993\end{array}$} \\
\hline & Mean & Std & Mean & Std & Mean & Std & Mean & Std \\
\hline Entrepreneurship rate $^{a}$ & 0.127 & 0.333 & 0.156 & 0.363 & 0.141 & 0.349 & 0.165 & 0.372 \\
\hline Proportion of Cohort 1992 & & & & & 0.509 & 0.500 & & \\
\hline Proportion of Cohort 1992 \& 1993 & & & & & & & 0.516 & 0.500 \\
\hline Male & 0.610 & 0.488 & 0.539 & 0.499 & 0.574 & 0.495 & 0.569 & 0.495 \\
\hline Married at graduation & 0.200 & 0.400 & 0.151 & 0.358 & 0.175 & 0.380 & 0.169 & 0.375 \\
\hline Ethnicity & 0.055 & 0.229 & 0.069 & 0.253 & 0.062 & 0.242 & 0.073 & 0.260 \\
\hline Number of siblings & 3.002 & 1.948 & 2.434 & 2.005 & 2.713 & 1.997 & 2.585 & 1.905 \\
\hline Grow up with two parents in the household & 0.946 & 0.227 & 0.894 & 0.308 & 0.919 & 0.272 & 0.899 & 0.302 \\
\hline Either of parents started their own business & 0.522 & 0.500 & 0.518 & 0.500 & 0.520 & 0.500 & 0.469 & 0.499 \\
\hline Active in sports & 0.709 & 0.455 & 0.721 & 0.449 & 0.715 & 0.452 & 0.707 & 0.455 \\
\hline Active in extra-curricular music/band & 0.564 & 0.496 & 0.529 & 0.500 & 0.546 & 0.498 & 0.504 & 0.500 \\
\hline Active in extra-curricular drama & 0.298 & 0.458 & 0.251 & 0.434 & 0.274 & 0.446 & 0.262 & 0.44 \\
\hline Active in extra-curricular academic clubs & 0.272 & 0.445 & 0.264 & 0.441 & 0.268 & 0.443 & 0.279 & 0.449 \\
\hline
\end{tabular}




\begin{tabular}{lccccccccc}
\hline Graduation Colleges & & & & & & & & \\
Agriculture and Life Sciences & 0.183 & 0.387 & 0.104 & 0.305 & 0.143 & 0.350 & 0.143 & 0.350 \\
Business & 0.105 & 0.306 & 0.173 & 0.378 & 0.139 & 0.346 & 0.152 & 0.359 \\
Design & 0.084 & 0.278 & 0.089 & 0.285 & 0.087 & 0.282 & 0.086 & 0.28 \\
Engineering & 0.200 & 0.401 & 0.164 & 0.371 & 0.182 & 0.386 & 0.179 & 0.383 \\
Human Sciences & 0.160 & 0.366 & 0.196 & 0.397 & 0.178 & 0.383 & 0.177 & 0.382 \\
\hline Observations & 725 & & 580 & & 1305 & & & & \\
\end{tabular}

Note: a: Entrepreneurship rate for Cohort 1982 and Cohort 1992 measures the proportion of individuals becoming entrepreneurs in fifteen years after their graduation. That is, the proportion of alumni starting businesses between 1982 and 1996 for Cohort 1982 and between 1992 and 2006 for Cohort 1992. Similarly, fifteen years criterion of entrepreneurship rate is for Cohort 1 and 2 (1:1982, 1983 and 2: 1992, 1993). The last sample includes alumni graduating between 1982 and 2004 whose entrepreneurship rate is likelihood to start a business within four years after graduation. Ethnicity is a dummy variable, equal to one if student is not white. There is a series of college dummies, measuring the college where alumni achieved their first Bachelor's degrees from ISU, with the base of College of Liberal Arts and Sciences. "Std" represents standard deviation. 


\section{Acknowledgement}

We gratefully acknowledge financial and in-kind support from the lowa State Foundation, the lowa State Alumni Association, the lowa State Registrar's Office, the Pappajohn Center for Entrepreneurship, and the lowa State Agricultural Entrepreneurship Program. 


\section{Reference}

Black, Sandra E. and Philip E. Strahan. 2002. Entrepreneurship and Bank Credit Availability. The Journal of Finance 57(6): 2807-2833.

Blanchflower, David and Andrew Oswald. 1998. What Makes an Entrepreneur? Journal of Labor Economics 16(1): 26-60.

Blanchflower, David. 2000. Self-employment in OECD countries. Labour Economics 7(5): 471-505.

Cagetti Marco and Mariacistina De Nardi. 2006. Entrepreneurship, Frictions and Wealth. Journal of Political Economy 114(5): 835-870.

Constant, Amelie and Klaus Zimmermann. 2004. Self-Employment Dynamics across the Business Cycle: Migrants versus Natives. IZA discussion paper No. 1386.

Evans, David S. and Linda S. Leighton. 1989. Some Empirical Aspects of Entrepreneurship. American Economic Review 79(3):519-535.

Fairlie, Robert W. 1999. The Absence of the African-American Owned Business: An Analysis of the Dynamics of Self-Employment. Journal of Labor Economics 17(1): 80-108.

Fairlie, Robert W. 2013. Entrepreneurship, economic conditions, and the Great Recession, Journal of Economics and Management Strategy 22(2): 207 - 231.

Fairlie, Robert W. and Bruce D. Meyer. 2000. Trends in Self-Employment Among White and Black Men. The Journal of Human Resources 35(4):643-669.

Fairlie, Robert W. and Alicia Robb. 2007. Families, Human Capital, and Small Business: Evidence from the Characteristics of Business Owners Survey. Industrial and Labor Relations Review 60(2): 225-245. 
Hamilton, Barton. 2000. Does Entrepreneurship Pay? An Empirical Analysis of the Returns to Self-Employment. Journal of Political Economy 108(3): 604-631.

Holtz-Eakin, Douglas, David Joulfaian and Harvey S. Rosen. 1994. Sticking It Out: Entrepreneurial Survival and Liquidity Constraints. Journal of Political Economy 102(1): 53-75.

Hout, Michael and Harvey S. Rosen. 2000. Self-Employment, Family Background and Race. The Journal of Human Resources 35(4):670-692.

Kahn, Lisa B. 2010. The long-term labor market consequences of graduating from college in a bad economy. Labour Economics 17(2): 303-316.

Lazear, Edward. 2005. Entrepreneurship. Journal of Labor Economics 23(4):649-680.

Meager, Nigel. 1992. Does Unemployment Lead to Self-Employment? Small Business Economics 4(2): 87-103.

Moore, Carol and Richard Mueller. 2002. The Transition into Self-Employment in Canada: The Importance of Involuntary Separation and Unemployment Duration. Applied Economics 34(6): 791-801.

Orazem, Peter F. and J. Peter Mattila. 1991. Human Capital, Uncertain Wage Distributions, and Occupational and Educational Choices. International Economic Review: 32(1): 103-122.

Oreopoulos, Phillip, Till von Wachter, and Andrew Heisz. 2012. The Short- and LongTerm Career Effects of Graduating in a Recession. American Economic Journal: Applied Economics 4(1): 1-29.

Parker, Simon C. 2009. The Economics of entrepreneurship. Cambridge: Cambridge University Press. 
Rampini, Adriano. 2004. Entrepreneurial activity, risk, and the business cycle. Journal of Monetary Economics 51(3): 555-573.

Shane, Scott. 2011. The great recession's effect on entrepreneurship. Economic commentary. Federal Reserve Bank of Cleveland. 
lowa State University does not discriminate on the basis of race, color, age, religion, national origin, sexual orientation, gender identity, genetic information, sex, marital status, disability, or status as a U.S. veteran. Inquiries can be directed to the Director of Equal Opportunity and Compliance, 3280 Beardshear Hall, (515) 294-7612. 